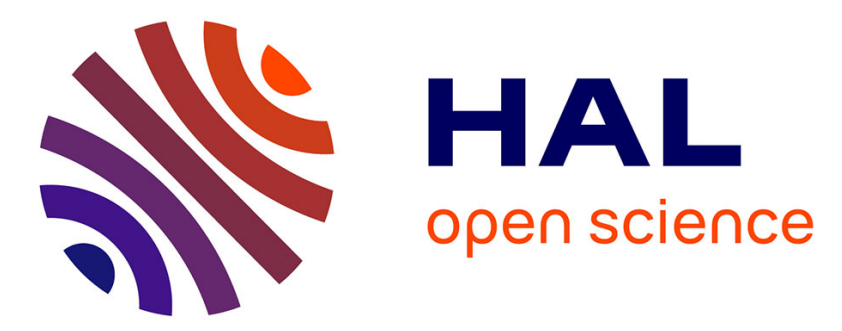

\title{
Characterization of a cytochrome P450 monooxygenase gene involved in the biosynthesis of geosmin in Penicillium expansum
}

Muhammad Hussnain Siddique, Thierry Liboz, Nafees Bacha, Olivier Puel, Florence Mathieu, Ahmed Lebrihi

\section{To cite this version:}

Muhammad Hussnain Siddique, Thierry Liboz, Nafees Bacha, Olivier Puel, Florence Mathieu, et al.. Characterization of a cytochrome P450 monooxygenase gene involved in the biosynthesis of geosmin in Penicillium expansum. African Journal of Microbiology Research, 2012, vol. 6 (19), pp. 4122-4127. 10.5897/AJMR11.1361 . hal-00937723

\section{HAL Id: hal-00937723 https://hal.science/hal-00937723}

Submitted on 28 Jan 2014

HAL is a multi-disciplinary open access archive for the deposit and dissemination of scientific research documents, whether they are published or not. The documents may come from teaching and research institutions in France or abroad, or from public or private research centers.
L'archive ouverte pluridisciplinaire HAL, est destinée au dépôt et à la diffusion de documents scientifiques de niveau recherche, publiés ou non, émanant des établissements d'enseignement et de recherche français ou étrangers, des laboratoires publics ou privés.

\section{(c)(1)}

Distributed under a Creative Commons Attribution| 4.0 International License 


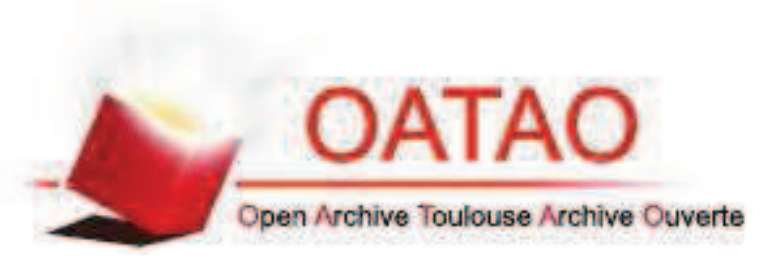

\section{Open Archive TOULOUSE Archive Ouverte (OATAO)}

OATAO is an open access repository that collects the work of Toulouse researchers and makes it freely available over the web where possible.

This is an author-deposited version published in : http://oatao.univ-toulouse.fr/ Eprints ID : 10812

To link to this article : DOI : 10.5897/AJMR11.1361

URL : http://academicjournals.org/journal/AJMR/articleabstract/841ECBA21771

To cite this version : Siddique, Muhammad Hussnain and Liboz, Thierry and Bacha, Nafees and Puel, Olivier and Mathieu, Florence and Lebrihi, Ahmed Characterization of a cytochrome P450 monooxygenase gene involved in the biosynthesis of geosmin in Penicillium expansum. (2012) African Journal of Microbiology Research, vol. 6 (n 19). pp. 4122-4127. ISSN 1996-0808

Any correspondance concerning this service should be sent to the repository administrator: staff-oatao@,1istes-diff.inp-toulouse.fr 


\title{
Characterization of a cytochrome P450 monooxygenase gene involved in the biosynthesis of geosmin in Penicillium expansum
}

\author{
Muhammad Hussnain Siddique ${ }^{1,2}$, Thierry Liboz ${ }^{1,2}$, Nafees Bacha ${ }^{3}$, Olivier Puel ${ }^{4}$, \\ Florence Mathieu ${ }^{1,2}$ and Ahmed Lebrihi ${ }^{1,2,5 *}$ \\ ${ }^{1}$ Université de Toulouse, INPT-UPS, Laboratoire de Génie Chimique, avenue de l'Agrobiopole, \\ 31326 Castanet-Tolosan Cedex, France. \\ ${ }^{2}$ Le Centre national de la recherche scientifique (CNRS), Laboratoire de Génie Chimique, 31030 Toulouse, France. \\ ${ }^{3}$ Centre of Biotechnology and Microbiology, University of Peshawar, Pakistan. \\ ${ }^{4}$ Institut National de la Recherche Agronomique (INRA), Laboratoire de Pharmacologie Toxicologie, 31931 Toulouse, \\ France. \\ ${ }^{5}$ Université Moulay Ismail, Marjane 2, BP 298, Meknes, Morocco.
}

\begin{abstract}
Geosmin is a terpenoid, an earthy-smelling substance associated with off-flavors in water and wine. The biosynthesis of geosmin is well characterized in bacteria, but little is known about its production in eukaryotes, especially in filamentous fungi. The origin of geosmin in grapevine is largely attributable to the presence of Penicillium expansum on grapes. Herein, we describe the characterization of "gpe1", a gene encoding a cytochrome P450 monooxygenase probably involved in the biosynthesis of geosmin in this species. A gpe1 knockout mutant of $P$. expansum M2230 lost the capacity to produce geosmin, while the genetically complemented mutant restored it. The deduced gpe1 protein sequence shows identities with other cytochrome P450 monooxygenases involved in diterpene biosynthesis. These enzymes catalyze the addition of hydroxyl groups to the diterpene compounds. gpe1 protein could work in the same way, with sesquiterpenes as substrates. This gene seems to be only present in geosmin-producing Penicillium species. To our knowledge, this is the first characterization of a fungal gene encoding an enzyme involved in geosmin biosynthesis.
\end{abstract}

Key words: Penicillium expansum, cytochrome P450 monooxygenase, geosmin.

\section{INTRODUCTION}

Geosmin (trans-1,10-dimethyl-trans-9-decalol) is a small volatile isoprenoid compound responsible for an earthysmelling off-flavor in water and foodstuffs, often associated with 2-methylisoborneol (Gerber and Lechevalier, 1965; Buttery and Garibaldi, 1976). It can be produced by many microorganisms, including actinomycetes, cyanobacteria, myxobacteria, several filamentous fungi, and may also be directly synthesized by liverworts, red beet, and insects (Izaguirre et al., 1982; Mattheis and Roberts, 1992; Omura et al., 2002; Spiteller

*Corresponding author. E-mail: Ahmed.Lebrihi@ensat.fr. et al., 2002; Lu et al., 2003; Dickschat et al., 2004; Zaitlin and Watson, 2006). Geosmin has a very low odor threshold, and numerous analysis methods are available (Cortada et al., 2011). Geosmin is notably found in drinking water and in grape juice. In the case of water, contamination is strictly bacterial (Jüttner and Watson, 2007), and physical, chemical and biological treatments exist (Cook et al., 2001; Kutschera et al., 2009; Eaton and Sandusky, 2010). In the case of wine, origin of geosmin is mainly due to the development of Penicillium expansum on grapes, with a possible impact of Botrytis cinerea (La Guerche et al., 2004; Morales-Valle et al., 2011). Removal or degradation processes will be detrimental to the organoleptic quality of wines, and 


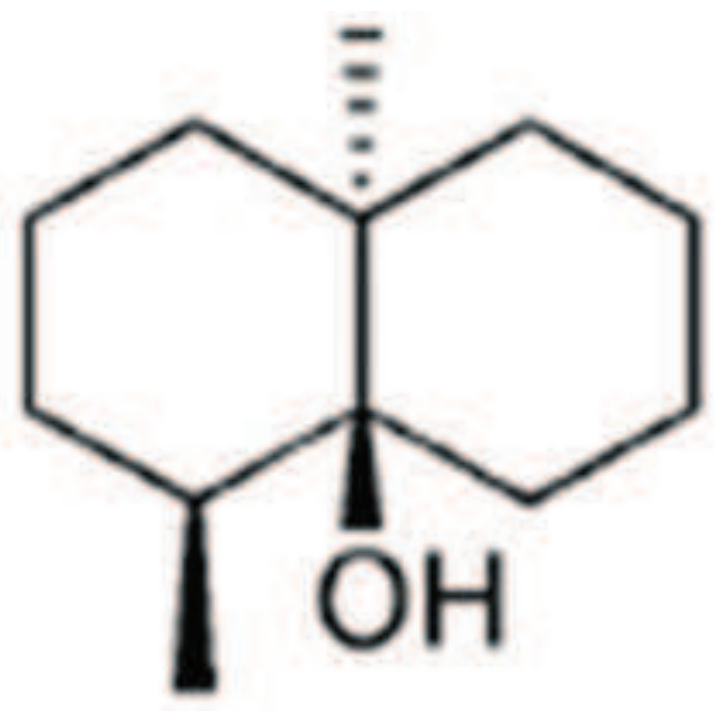

Figure 1. Chemical structure of geosmin.

cannot be applied. Nowadays, predictive models of fungal growth are therefore the best way to control geosmin production (Judet-Correia et al., 2010).

In this context, a better knowledge of the geosmin biosynthesis pathway in filamentous fungi will help to define new strategies to reduce contamination in grapevine products. This pathway is well characterized in bacteria, especially in the genus Streptomyces. A bifunctional germacradienol/geosmin synthase catalyze the conversion of farnesyldiphosphate, a primary metabolite, into geosmin in a two-step process (Jiang et al., 2007). Until today, no germacradienol/geosmin synthase has been characterized in eukaryotic species to our knowledge. Bioinformatics analysis (screening of genes encoding this enzyme) gave no results in the genus Penicillium, suggesting a different geosmin biosynthesis pathway in $P$. expansum. Geosmin structure, and the presence of one hydroxyl group (Figure 1), may lead to other enzymes, like cytochrome P450 monooxygenases, as has been suggested in bacteria (Lamb et al., 2003). These enzymes are involved in many metabolic pathways, including the biosynthesis of terpenes and their derivatives (Cresnar and Petric, 2011).

During 2006 White et al. (2006) characterize two DNA fragments, $p 450-1$ and $p 450-2$, corresponding to parts of putative cytochrome P450 monooxygenase genes in $P$. expansum (strain IBT 21771) by suppression subtractive hybridization. As these two fragments were isolated from population of transcripts preferentially expressed under patulin-permissive conditions, the authors concluded to their involvement in patulin biosynthesis.

More recently, the two cytochrome P450 genes needed for patulin biosynthesis were functionally characterized in Aspergillus clavatus (Artigot et al., 2009). Sequences alignments revealed weak identities (28\%) between these two genes and those from $P$. expansum, suggesting another role for $p 450-1$ and $p 450-2$. The latter showed higher similarities (40\% on average) with cytochrome P450 involved in terpene metabolism and lower (less than $30 \%$ ) with those involved in polyketide metabolism (as patulin for example).

In this study, we report the characterization of a P450 gene (gpe1) required for the geosmin biosynthesis in $P$. expansum.

\section{MATERIALS AND METHODS}

\section{Fungal strain and culture conditions}

$P$. expansum $\mathrm{M} 2230$ strain was grown for sporulation at $28^{\circ} \mathrm{C}$ on Yeast Extract Sucrose (YES) Agar medium (Yeast extract, $20 \mathrm{~g}$; Sucrose, 150 g; Agar, 20 g; Distilled water, 1 L) for 7 days. Spores were collected using a solution of $0.01 \%(\mathrm{v} / \mathrm{v})$ Tween 80 , counted and stored at $-20^{\circ} \mathrm{C}$ in $25 \%(\mathrm{v} / \mathrm{v})$ glycerol before use. Conidia were inoculated (density 106 $/ \mathrm{mL}$ ) into $250 \mathrm{~mL}$ Erlenmeyer flasks containing $100 \mathrm{~mL}$ YES broth medium, and incubated at $28^{\circ} \mathrm{C}$ for 4 days, without shaking. Mycelium was harvested by filtration through a $0.45 \mu \mathrm{M}$ filter, grounded in liquid nitrogen and then stored at $80^{\circ} \mathrm{C}$ before nucleic acid extraction.

\section{DNA extraction and purification}

Extraction of genomic fungal DNA was done by a rapid extraction method (Liu et al., 2000). The extraction of DNA from plasmids was done by using a Pure Link Plasmid Miniprep Kit (Invitrogen, France). The extraction of DNA from gel was performed by the QIAquick Gel Extraction Kit (QIAGEN, France). The PCR products were purified using the QIAquick PCR Purification Kit (QIAGEN, France). The quality and quantity of DNA were estimated by measuring optical density (OD), that is, OD $260 \mathrm{~nm} / \mathrm{OD} 280 \mathrm{~nm}$ and OD $260 \mathrm{~nm}$ respectively and by agarose (Promega, France) gel electrophoresis.

\section{PCR amplifications}

PCR amplifications were performed in $25 \mu \mathrm{L}$ reaction mixtures containing $2.5 \mu \mathrm{L}$ of Taq polymerase $10 \mathrm{X}$ buffer with $\mathrm{MgCl}_{2}, 0.5 \mu \mathrm{L}$ of dNTPs mix $10 \mathrm{mM}$ each, $0.5 \mu \mathrm{L}$ of each primer $10 \mathrm{mM}, 1 \mathrm{U}$ of Taq polymerase (MP Biomedicals, France), $200 \mathrm{ng}$ of genomic DNA, sterile deionized $\mathrm{H}_{2} \mathrm{O}$ upto $25 \mu \mathrm{L}$. Reaction conditions were: $94^{\circ} \mathrm{C}$ for $4 \mathrm{~min}$ (initial denaturation), 30 cycles at $94^{\circ} \mathrm{C}$ for $45 \mathrm{~s}$ (denaturation), 2-5 degrees Celsius below the $\mathrm{T}_{\mathrm{m}}$ of both primers for $45 \mathrm{~s}$ (annealing), and $72{ }^{\circ} \mathrm{C}$ for $1 \mathrm{~min}$ (elongation). A final elongation for $10 \mathrm{~min}$ at $72^{\circ} \mathrm{C}$ was added.

\section{Disruption of gpe1 P450 gene in P. expansum M2230}

The disruption of gpe1 was done by inserting the $E$. coli hygromycin B phosphotransferase gene ( $h p h)$ flanked by $A$. nidulans trpC promoter and terminator sequences from plasmid pID2.1, as previously described by Bacha et al. (2009) and as illustrated in Figure 2. After construction of the transformation vector (Figure 2a), gpe 1 inactivation was achieved by transformation of $P$. expansum M2230 protoplasts with TopoPhph (Figure 2b). Complementary mutants were obtained by transformation of $\Delta g p e 1$ protoplasts with TopoP (Figure 2c). $40 \mathrm{mg} / \mathrm{mL}$ lysing enzymes (Sigma, France) were used for the preparation of protoplasts. 

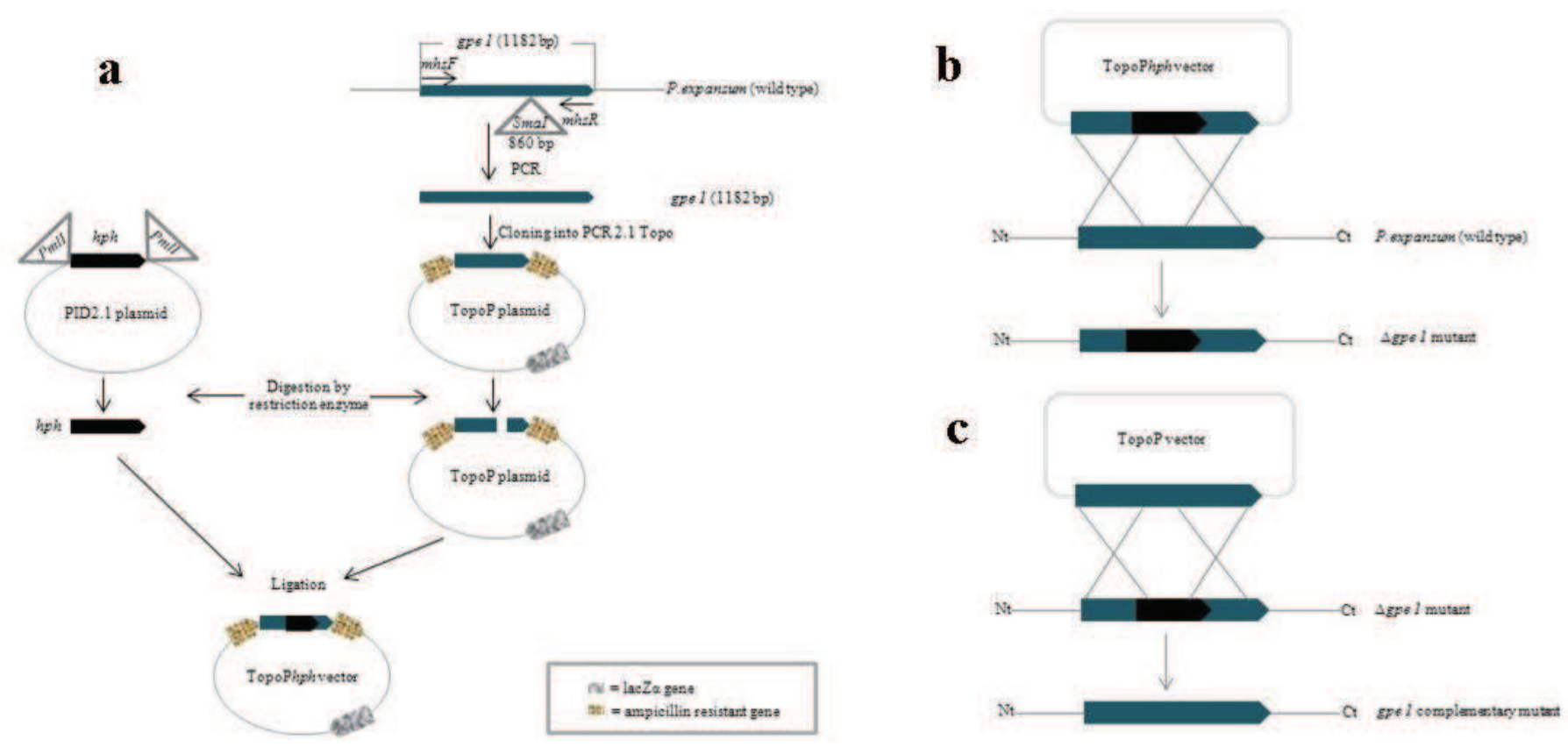

Figure 2. Schematic representation of transformation vector formation and gpel gene disruption. (a) Using primer pair $m h s F / m h s R$ (Table 1), 1182 bp gpe1 gene containing Smal restriction site (indicated by triangle) was amplified. PCR product was cloned into PCR2.1-Topo plasmid to generate plasmid TopoP. PID2.1 plasmid vector was restricted with Pmll (indicated by triangle) to obtain $h p h$ cassette (1032 bp). TopoP was restricted with Sma1 and ligated with $h p h$ cassette to generate TopoPhph transformation vector. (b) Protoplasts of $P$. expansum (wt) were prepared and gpe1 gene was disrupted using TopoPhph vector to obtain $\Delta$ gpe 1 mutant. (c) Protoplasts of $\Delta g p e 1$ mutant were prepared and gpe1 gene was restored using TopoP vector to obtain gpe1 complementary mutant.

\section{Screening of the transformants}

Hygromycin-resistant transformants were selected on YES medium (20 g/L of yeast extract, $1 \mathrm{M}$ sucrose, $15 \mathrm{~g} / \mathrm{L}$ of agar) supplemented with $150 \mu \mathrm{g} / \mathrm{mL}$ of hygromycin B. Transformant plates were incubated at room temperature for $24 \mathrm{~h}$ and then transferred to $28^{\circ} \mathrm{C}$ for 4 days. Hygromycin resistant transformants were further screened through a PCR, using $h p h$ gene specific primers $h p h F$ and $h p h R$ (Table 1). Positive transformants were then subjected to a second PCR using P450 gene specific primer $m h s F$ with $h p h R$. To screen the genetically complemented mutants, each of the colonies grown after $48 \mathrm{~h}$ of incubation was divided into two parts. One part was transferred to a Petri dish containing YES medium without hygromycin and the other part to another Petri dish containing YES medium with hygromycin (final concentration of 150 $\mu \mathrm{g} / \mathrm{mL}$ ). The colonies which grew successfully on YES medium without hygromycin but not on YES medium with hygromycin were subjected to different PCRs (as described above in case of mutants) for further screening.

\section{Quantification of geosmin production}

The production of geosmin was quantified from 10 days old culture of $P$. expansum wild type, $\Delta g p e 1$ mutant and gpe 1 complementary mutant strains grown in Petri dishes containing YES medium. We put all the mycelium along with medium in a tube after cutting it into small pieces with a sterile surgical blade. $10 \mathrm{~mL}$ of $20 \%$ ethanol were added in each tube containing all the mycelium of relevant strain. After vortexing, the tubes were incubated at room temperature at $200 \mathrm{rpm}$ for $1 \mathrm{~h}$. Then, filtered samples were sent to Exact Laboratory at Macon (France) for quantification of geosmin production, done by gas chromatography-mass spectrometry (GC$M S)$, with a limit of quantification of $10 \mathrm{ng} / \mathrm{L}$.

\section{Data analysis}

The deduced amino acid sequence was determined using the http://www.expasy.org/tools/dna.html site while protein-protein Blast (Blastp) searches were conducted at the GenBank database http://www.ncbi.nlm.nih.gov. The alignments were conducted using the website http://multalin.toulouse.inra.fr/multalin. The sequence obtained was deposited in Genbank under the accession number JN126314.

\section{RESULTS AND DISCUSSION}

Considering that $P$. expansum also produce geosmin, and that this molecule belongs to the terpene family, so what about the involvement of $p 450-1$ and $p 450-2$ in geosmin biosynthesis? Moreover, these two partial sequences seemed to match with different parts of the same protein.

For this two primers were designed, mhsF corresponding to the 5' end of p450-2 and $m h s R$ corresponding to the 3 ' end of $p 450-1$ (Table 1). This allowed the amplification and the sequencing of a single 1182 bp $P$. expansum (strain M2230) gene fragment. The corresponding amino acid sequence (394 residues) 
Table 1. PCR primers used in this study.

\begin{tabular}{cl}
\hline Primer name & Sequence (5'-3') \\
\hline$m h s F$ & CGAAATTCTGCTGGAAAGCG \\
$m h s R$ & ATTGGCTTTTCCCGTTCACG \\
$h p h F$ & GAATTCAGCGAGAGCCTGAC \\
$h p h R$ & ACATTGTTGGAGCCGAAATC \\
\hline
\end{tabular}

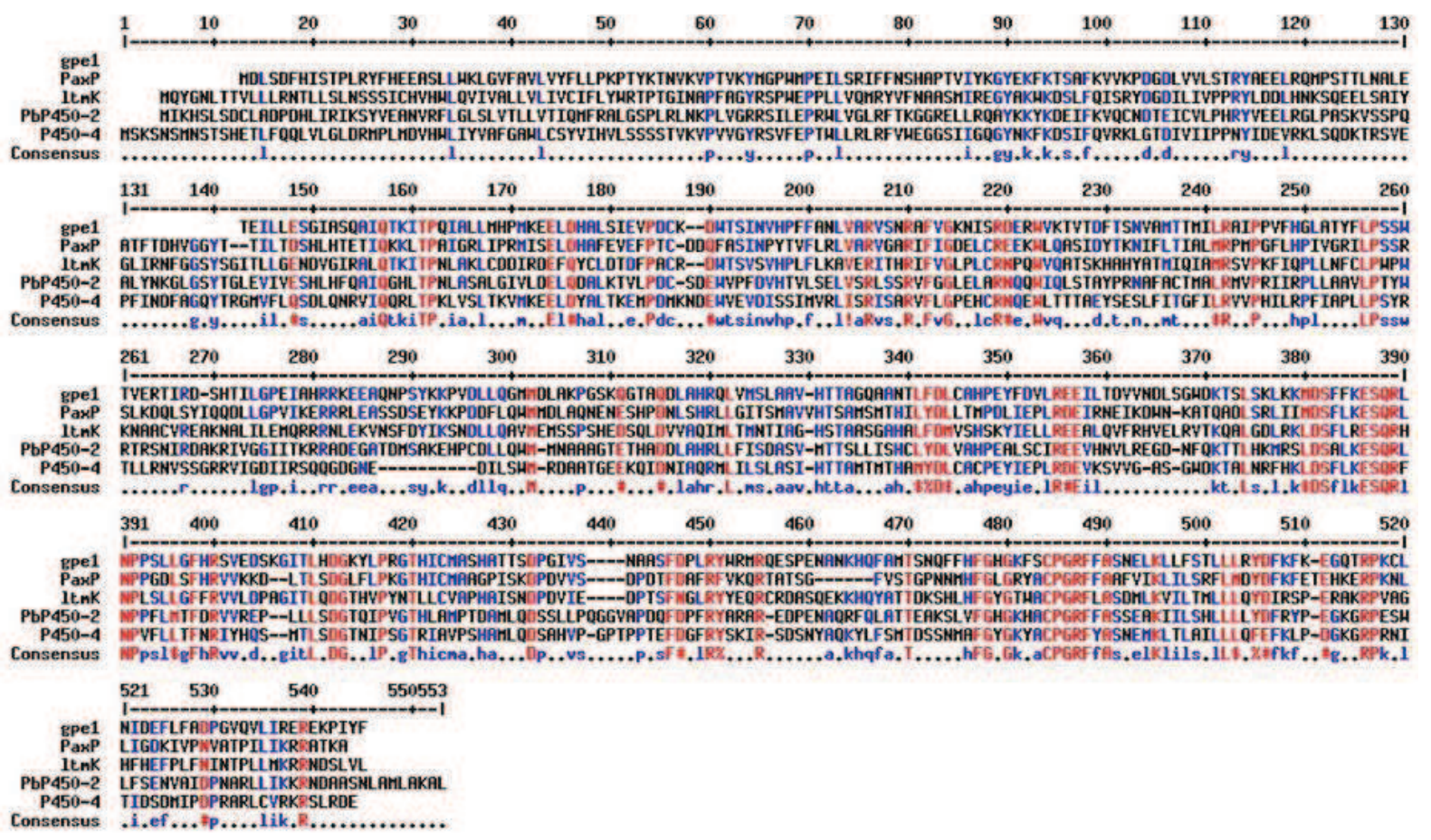

Figure 3. Alignment of the deduced amino acid sequence of gpe1 with other cytochrome P450 monooxygenases genes: Pax $P$ (Accession No. AAK11528) of Penicillium paxilli involved in the biosynthesis of paxilline, Itm K (Accession No. AAW88512) of Neotyphdium lolii involved in the biosynthesis of lolitrem, PbP450-2 (Accession No. BAD29968) of Phoma betae involved in the biosynthesis of aphidicolin and P450-4 (Accession No. Q701P2.1) of Gibberella fujikuroi involved in the biosynthesis of gibberellin.

displayed conserved domains of cytochromes P450 monooxygenases (CYP) like the heme-binding loop and the Glu-X-X-Arg motif (Werck-Reichhart and Feyereisen, 2000), and showed no similarities with flavin-containing monooxygenases (FMO).

Alignment of gpe1 with other cytochromes P450 monooxygenases displayed an average identity of $40 \%$ to the central and $\mathrm{N}$-terminal parts of enzymes involved in indole diterpene synthesis and in gibberellin synthesis (Figure 3). These enzymes catalyze the addition of hydroxyl groups after cyclization of the diterpenes (Saikia et al., 2008). Replacement of geranylgeranyl diphosphate (diterpene) as a precursor by farnesyldiphosphate (sesquiterpene) can probably lead to the formation of geosmin in a similar process. Farnesyldiphosphate is also an intermediate in geosmin biosynthesis in bacteria (Jiang et al., 2007), and some cyanobacteria have cytochromes P450 monooxygenases involved in the production of sesquiterpenes (Robert et al., 2010). All of these data suggest a possible role of gpe 1 protein as a CYP involved in geosmin biosynthesis.

To confirm this hypothesis, the same primers $m h s F$ and $m h s R$ were first used for PCR amplifications in fourteen Penicillium species. The ten geosmin-producing species (including $P$. expansum) showed the same 1,2 kb PCR product, whereas the four non-producing species gave no signal, or a weaker smaller band (Figure 4).

Therefore the gpe1 gene was functionally characterized in $P$. expansum $\mathrm{M} 2230$, by the gene disruption method. To obtain mutants of gpe1, protoplasts issued from $P$. expansum M2230 cells were transformed with TopoPhph vector (Figure 2). Forty two transformants which were able to grow on YES medium added with hygromycin were subsequently screened by two consecutive PCRs to 


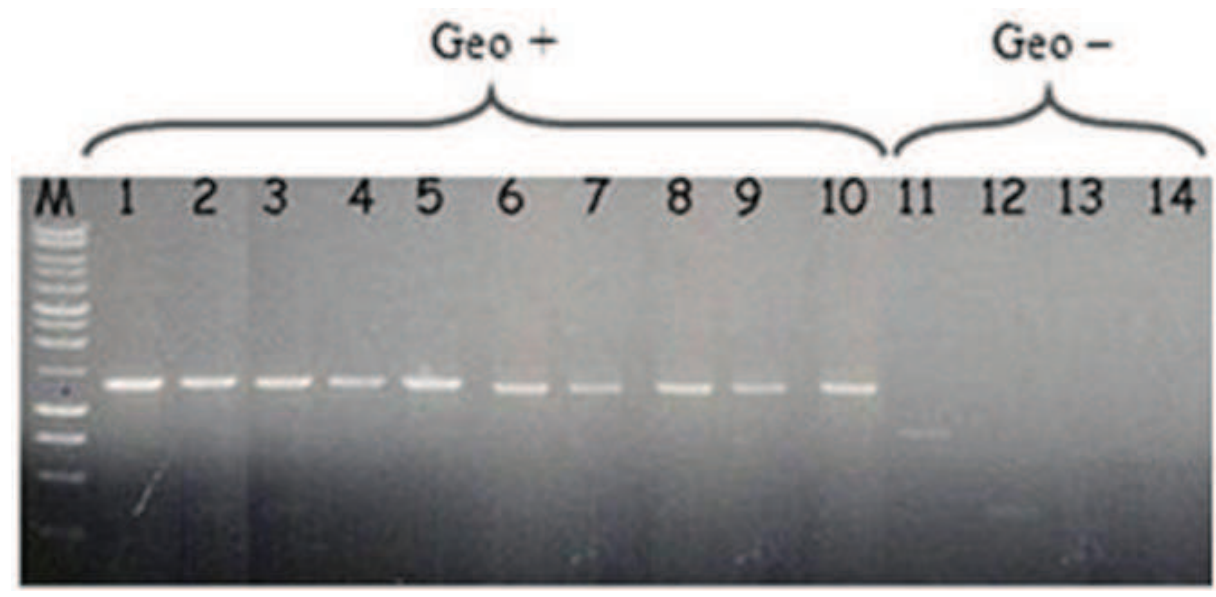

Figure 4. gpe1 PCR amplification on geosmin productive (1-10) and non-productive (11-14) Penicillium species: 1. P. aureo-cinnamomeum, 2. P. sclerotiorum, 3. P. spinulosum, 4. P. bilaiae, 5. $P$. spinulosum, 6. $P$. canescens, 7. $P$. paraherquei, 8. $P$. expansum, 9. $P$. minioluteum, 10. P. geastrivorus, 11. $P$. brevicompactum, 12. $P$. ochrochoron, 13. $P$. restrictum, 14. P. crustosum, M: 1 kb DNA ladder.

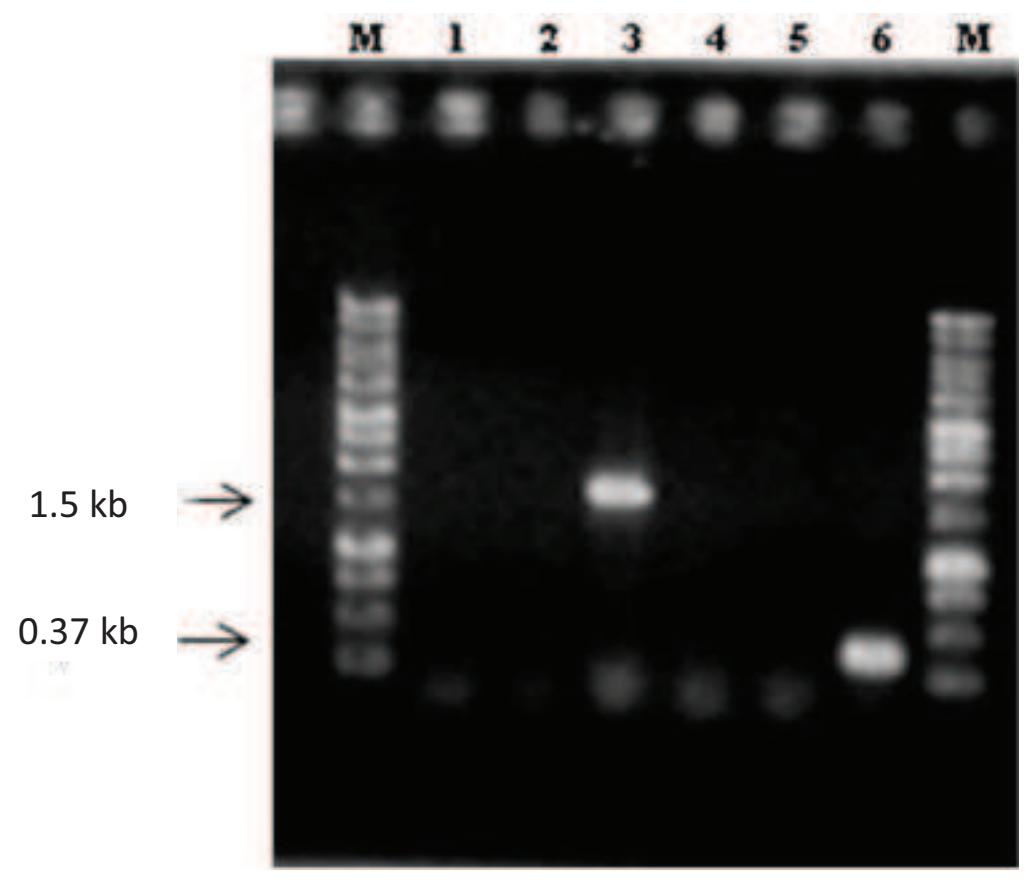

Figure 5. PCR transformants screening : 1. P. expansum wild type with primers mhsF/hphR, 2. gpe1 complementary mutant with primers $m h s F / h p h R, 3$. $\Delta g p e 1$ mutant with $m h s F / h p h R, 4$. P. expansum wild type with primers $h p h F / h p h R, 5$. gpe1 complementary mutant with primers $h p h F / h p h R$, 6. $\Delta g p e 1$ mutant with $h p h F / h p h R$. M: 1kb DNA ladder.

monitor the integration of $h p h$ cassette in the genome of $P$. expansum.Using primer pair hphF/hphR, a PCR product of $\sim 0.37 \mathrm{~kb}$ (corresponding to hph cassette) was obtained in only five transformants (Figure 5, lane 6).
These five transformants were then subjected to a second PCR using primers $m h s F$ and $h p h R$. All gave a $\sim 1.5 \mathrm{~kb}$ gpe1/hph fragment (Figure 5, lane 3). No PCR amplification was observed in the wild type $P$. expansum 
with any of the primers combination (Figure 5, lanes 1 and 4).

Geosmin was not detected (limit of quantification 10 $\mathrm{ng} / \mathrm{L}$ ) in each of the mutants, while the production of the wild $P$. expansum $\mathrm{M} 2230$ strain was $14 \mathrm{ng} / \mathrm{L}$.

To produce reverse complements, $\Delta g p e 1$ mutant protoplasts were transformed with TopoP vector. The transformants which only grew on YES medium but not on YES medium supplemented with hygromycin were selected. These selected transformants were subjected to the same two screening PCRs using primer pairs $h p h F / h p h R$ and $m h s F / h p h R$. No amplification product in complementary mutants with any of the primer pairs depicts the removal of hph cassette (Figure 5, lanes 2 and 5 ). Geosmin production by the reverse complements was identical to the production of the wild $P$. expansum M2230 strain (14 $\mathrm{ng} / \mathrm{L})$. So the conclusion of this is the proposition that gene gpe1 encodes a cytochrome P450 monooxygenase involved in the biosynthesis of geosmin.

The fact that the initial DNA fragments $p 450-1$ and p450-2 were isolated from population of transcripts preferentially expressed under patulin-permissive conditions is compatible with our proposition: numerous studies have shown the interactions between different secondary metabolic pathways. If geosmin derives from farnesyldiphosphate, its biosynthesis probably starts with acetyl CoA, via the mevalonate pathway, suggesting concerted regulation process. Such a phenomenon depending on the availability of acetyl CoA was already described for geosmin, with an interaction with doxorubicin synthesis (Singh et al., 2009).

In further studies, the use of gpe1 gene, as a probe, could allow to the characterization of other genes involved in the biosynthetic pathway of geosmin.

\section{ACKNOWLEDGMENTS}

We are grateful to the Higher Education Commission of Pakistan for granting a Ph.D scholarship to Mr. Muhammad Hussnain Siddique.

\section{REFERENCES}

Artigot MP, Loiseau N, Laffitte J, Mas-Reguieg L, Tadrist S, Oswald IP, Puel $O$ (2009). Molecular cloning and functional characterization of two CYP619 cytochrome P450s involved in biosynthesis of patulin in Aspergillus clavatus. Microbiology, 155: 1738-1747.

Bacha N, Atoui A, Mathieu F, Liboz T, Lebhiri A (2009). Aspergillus westerdijkiae polyketide synthase gene aoks1 is involved in the biosynthesis of ochratoxin A. Fungal Genet. Biol., 46: 77-84.

Buttery RG, Garibaldi JA (1976). Geosmin and methylisoborneol in garden soil. J Agric. Food Chem., 24: 1246-1247.

Cook D, Newcombe G, Sztajnbok P (2001). The application of powdered activated carbon for MIB and geosmin removal: predicting PAC doses in four raw waters. Water Res., 35: 1325-1333.

Cortada C, Vidal L, Canals A (2011). Determination of geosmin and 2methylisoborneol in water and wine samples by ultrasound-assisted dispersive liquid-liquid microextraction coupled to gas chromatography-mass spectrometry. J. Chromatogr. A., 1218: 17-22.

Cresnar B, Petric S (2011). Cytochrome P450 enzymes in the fungal kingdom. Biochim. Biophys. Acta, 1814: 29-35.

Dickschat JS, Wenzel SC, Bode HB, Muller R, Schulz S (2004). Biosynthesis of volatiles by the myxobacterium Myxococcus xanthus. Chembiochemistry, 5: 778-787.

Eaton RW, Sandusky P (2010). Biotransformations of (+/-)-geosmin by terpene-degrading bacteria. Biodegradation, 21: 71-79.

Gerber NN, Lechevalier HA (1965). Geosmin, an earthly-smelling substance isolated from actinomycetes. Appl. Microbiol., 13: 935-938.

Izaguirre G, Hwang CJ, Krasner SW, Mcguire MJ (1982). Geosmin and 2-Methylisoborneol from cyanobacteria in three water supply systems. Appl. Environ. Microbiol., 43: 708-714.

Jiang J, He X, Cane DE (2007). Biosynthesis of the earthy odorant geosmin by a bifunctional Streptomyces coelicolor enzyme. Nat. Chem. Biol., 3: 711-715.

Judet-Correia D, Bollaert S, Duquenne A, Charpentier C, Bensoussan M, Dantigny $P$ (2010). Validation of a predictive model for the growth of Botrytis cinerea and Penicillium expansum on grape berries. Int. J. Food Microbiol., 142: 106-113.

Jüttner F, Watson SB (2007). Biochemical and ecological control of geosmin and 2-methyisoborneol in source waters. Appl. Environ. Microbiol., 73: 4395-4406.

Kutschera K, Börnick H, Worch E (2009). Photoinitiated oxidation of geosmin and 2-methylisoborneol by irradiation with $254 \mathrm{~nm}$ and 185 nm UV light. Water Res., 43: 2224-2232.

La Guerche S, Garcia C, Darriet P, Dubourdieu D, Labarère J (2004). Characterization of Penicillium species isolated from grape berries by their internal transcribed spacer (ITS1) sequences and by gas chromatography-mass spectrometry analysis of geosmin production. Curr. Microbiol., 48: 405-411.

Lamb DC, Ikeda H, Nelson DR, Ishikawa J, Skaug T, Jackson C, Omura S, Waterman MR, Kelly SL (2003). Cytochrome P450 complement (CYPome) of the avermectin-producer Streptomyces avermitlis and comparison to that of Streptomyces coelicolor A3(2). Biochem. Bioph. Res. Commun., 307: 610-619.

Liu D, Coloe C, Baird R, Pedersen J (2000). Rapid mini-preparation of fungal DNA for PCR. J. Clin. Microbiol., 38: 471.

Lu G, Edwards CG, Fellman JK, Mattinson DS, Navazio J (2003). Biosynthetic origin of geosmin in red beets (Beta vulgaris L.). J. Agric. Food Chem., 51: 1026-1029.

Mattheis JP, Roberts RG (1992). Identification of geosmin as a volatile metabolite of Penicillium expansum. Appl. Environ. Microbiol., 58: 3170-3172.

Morales-Valle H, Silva LC, Paterson RRM, Venâncio A, Lima N (2011). Effects of the origins of Botrytis cinerea on earthy aromas from grape broth media further inoculated with Penicillium expansum. Food Microbiol., 28: 1048-1053.

Omura H, Kuwahara Y, Tanabe T (2002). 1-Octen-3-OL together with geosmin: new secretion compounds from a polydesmid millipede, Niponianodulosa. J. Chem. Ecol., 28: 2601-2612.

Robert FO, Pandhal J, Wright PC (2010). Exploiting cyanobacterial P450 pathways. Curr. Opin. Microbiol., 13: 301-306.

Saikia S, Nicholson MJ, Young C, Parker EJ, Scott B (2008). The genetic basis for indole-diterpene chemical diversity in filamentous fungi. Mycol. Res., 112: 184-199.

Singh B, Oh TJ, Sohng JK (2009). Exploration of geosmin synthase from Streptomyces peucetius ATCC 27952 by deletion of doxorubicin biosynthetic gene cluster. J. Ind. Microbiol. Biotechnol., 36: 12571265.

Spiteller D, Jux A, Piel J, Boland W (2002). Feeding of $\left[5,5-{ }^{2} \mathrm{H}_{2}\right]-1$ desoxy-D-xylulose and $\left[4,4,6,6,6-{ }^{2} \mathrm{H}_{5}\right]$-mevalolactone to a geosminproducing Streptomyces sp. and Fossombronia pusilla. Phytochemistry, 61: 827-834.

Werck-Reichhart D, Feyereisen R (2000). Cytochromes P450: a success story. Genome Biol., 1: 3003.1-9.

White S, O'Callaghan J, Dobson ADW (2006). Cloning and molecular characterization of Penicillium expansum genes upregulated under conditions permissive for patulin biosynthesis. FEMS Microbiol. Lett., 255: 17-26.

Zaitlin B, Watson SB (2006). Actinomycetes in relation to taste and odour in drinking water: Myths, tenets and truths. Water Res., 40: 1741-1753. 